\title{
Influence of Moisture Stress Management Practices on the Performance of Summer Irrigated Maize (Zea mays L.)
}

\author{
M. Rajasekar ${ }^{1^{*}}$ and N. K. Prabhakaran ${ }^{2}$ \\ ${ }^{1}$ Department of Agronomy AC \& RI, Kudumiyanmalai, Pudukottai- 622 104, India \\ ${ }^{2}$ Agricultural Research Station, Bhavanisagar - 638 451, India \\ *Corresponding author
}

Keywords

Deficit irrigation,

Irrigation

scheduling, PPFM,

Silicic acid,

Brassinolide

Article Info

Accepted:

15 March 2020

Available Online:

10 April 2020
A field experiment was conducted at Agricultural Research Station, Bhavanisagar, Tamil Nadu, India during summer 2018 and 2019 to study the influence of moisture stress management practices on plant growth and yield of maize. Study revealed that, irrigation scheduling at IW/CPE 1.0 produced higher plant height $(217.6 \mathrm{~cm})$, leaf area index $(3.77)$, dry matter production $\left(16159 \mathrm{~kg} \mathrm{ha}^{-1}\right)$ and yield $\left(6715 \mathrm{~kg} \mathrm{ha}^{-1}\right)$ and was comparable with IW/CPE ratio of 0.8 . Among the moisture stress management practices foliar application of PPFM $1 \%$ at 25 and 45 DAS recorded significantly higher plant height $(209.7 \mathrm{~cm})$, leaf area index $(3.62)$, dry matter production $\left(15505 \mathrm{~kg} \mathrm{ha}^{-1}\right)$ and yield $\left(6381 \mathrm{~kg} \mathrm{ha}^{-1}\right)$. Higher net return (55535 Rs. ha ${ }^{-1}$ ) and benefit cost ratio (2.71) was realized under IW/CPE 0.8. In moisture stress management practices foliar application of PPFM @ 1\% recorded higher net return (51455 Rs. ha ${ }^{-1}$ ) and benefit cost ratio (2.56). Results from the study indicated that, irrigating at IW/CPE ratio of 0.8 was good enough to produce maximum yield and net return in normal water availability condition. While under water scarcity condition IW/CPE ratio of 0.6 coupled with foliar application of PPFM $1 \%$ at 25 and 45 DAS was more reliable for sustaining yield and net return.

\section{Introduction}

Maize (Zea mays L.) is the third most important cereal crop in India after rice and wheat and plays important role in agricultural economy as food for larger section of population, raw materials for industries and feed for animals. Drought is the main constraint for maize crop, causing severe yield reductions by $40 \%$ on a global scale (Daryanto et al., 2016). Irrigation water is becoming critical scarce resource and expensive due to higher demand by industry and urban consumption. The ground water is depleting at an alarming rate (GOR, 2007) and therefore framing strategies to reduce irrigation water losses and enhance crop water productivity has driven special attention. 
Deficit irrigation is an option where water availability limits conventional irrigation and reduces the risk of yield reduction due to terminal dry spell (Singh et al., 2010).

Pink pigmented facultative methylotrophic bacteria (PPFM) are associated with the roots, leaves and seeds of most terrestrial plants and utilize volatile $\mathrm{C}_{1}$ compounds such as methanol generated by growing plants at cell division phase (Irvine et al., 2012), increasing $\mathrm{CO}_{2}$ concentration inside stomata leading to accelerated rate of photosynthesis and decreased the rate of photorespiration in $\mathrm{C}_{3}$ plants (Wingler et al., 2000). During dry spell PPFM exudates osmo protectants (sugars and alcohols) on the surface of host plants and this matrix helps to protect the plants from desiccation and high temperature (Irvine et al., 2012).

Silicon is an important element, and plays an important role in inducing tolerance to the plants from environmental stresses (Tripathi et al., 2014). Increased Silicon (Si) supply improves the structural integrity of crops and may also improve plant tolerance to diseases, drought and metal toxicities (Ma, 2004). Siinduced growth improvement under waterdeficit conditions has been observed in different species such as wheat (Gong et al., 2012), rice (Chen et al., 2011), and soybean (Shen et al., 2010).

Brassinolide is a steroidal growth regulator has emerged as a new phytohormone with pleiotropic effect (Sasse, 1997), and influences varied physiological processes like germination, growth, flowering, senescence and confers resistance to the plant against various abiotic stresses. Brassinosteroids have been identified to improve the resistance of plants against environmental stresses such as water stress, salinity stress, low temperature stress and high temperature stress (Rao et al., 2002). Moreover brassinolides have also been picked out as plant growth and development signals (Ryu et al., 2007)

In this regard the present study was aimed at identifying suitable irrigation regime and investigating the effect of moisture stress management practices plant on the growth and yield stability of maize.

\section{Materials and Methods}

The experiment was conducted at Agricultural Research Station, Bhavanisagar $\left(11^{\circ} 29^{\prime} \mathrm{N}\right.$, $77^{\circ} 08^{\circ} \mathrm{E}$, and $256 \mathrm{~m}$ above the mean sealevel), Tamil Nadu, India during 2018 and 2019. The soil at experimental site was sandy loam (28.0\% clay, $20.6 \%$ silt, $22.3 \%$ course sand and $29.1 \%$ fine sand) medium in organic carbon $(0.51 \%)$, low in available nitrogen $\left(245.0 \mathrm{~kg} \mathrm{ha}{ }^{-1}\right)$, medium in phosphorus (12.8 $\mathrm{kg} \mathrm{ha}^{-1}$ ) and high potassium (446.2 $\mathrm{kg} \mathrm{ha}^{-1}$ ). During the crop growth (Feb - May) of 2018 and 2019, monthly mean maximum and minimum temperature ranged between $35.6^{\circ} \mathrm{C}$ and $24.3^{\circ} \mathrm{C} ; 37.1^{\circ} \mathrm{C}$ and $23.7^{0} \mathrm{C}$ respectively. The experimental site received rainfall of $79.3 \mathrm{~mm}$ in seven rainy days during summer 2018 and $118.3 \mathrm{~mm}$ in five rainy days during summer 2019. The mean evaporation was 4.4 to $7.2 \mathrm{~mm}$ and 3.5 to $7.2 \mathrm{~mm}$ in summer 2018 and 2019 respectively.

The experiment was laid out in split plot design comprised of four irrigation regimes based on IW/CPE ratio as main factor viz., IW/CPE ratio of $1.0\left(\mathrm{I}_{1.0}\right)$, IW/CPE ratio of $0.8\left(\mathrm{I}_{0.8}\right)$, IW/CPE ratio of $0.6\left(\mathrm{I}_{0.6}\right)$ and IW/CPE ratio of $0.4\left(\mathrm{I}_{0.4}\right)$ and four treatments in the sub plot viz., foliar application of pink pigmented facultative methylobacteria at $1 \%$ (FPFM), Foliar application of Brassinolide 0.1 ppm $\left(\mathrm{F}_{\mathrm{Br}}\right)$, Foliar application of silicic acid $0.2 \%\left(\mathrm{~F}_{\mathrm{Sl}}\right)$ and control $\left(\mathrm{F}_{\text {cont }}\right)$ as a sub factor. Foliar application was given on 25 DAS and 45 DAS for each treatment in the sub plot. 
Maize cultivar $\mathrm{CO}(\mathrm{H}) \mathrm{M} 6$ was used as a test variety with $60 \mathrm{~cm}$ row spacing and $25 \mathrm{~cm}$ between the plants. Recommended dose of NPK for maize hybrid 250:75: $75 \mathrm{~kg} \mathrm{ha}^{-1}$ was adopted as per crop management practices.

Irrigation was given at the time of sowing and the life irrigation on the fifth day and following subsequent irrigations were scheduled based on the irrigation regimes of the main plot as per the IW/CPE ratio and irrigated at a depth of $50 \mathrm{~mm}$ measured using parshall flume.

\section{Results and Discussion}

\section{Plant height at harvest}

Irrigation regime and water deficit management exerted significant influence on the plant height of maize (Table 1). IW/CPE 1.0 recorded significantly higher $(217.6 \mathrm{~cm})$ and comparable plant height with IW/CPE 0.8. There was progressive increase in plant height with increase in soil moisture content and was justified with the findings of Alagar Pandyan and Iruthayaraj (1991).

Among the moisture stress management treatments significantly higher plant height $(209.7 \mathrm{~cm})$ was recorded in foliar application of PPFM 1\% 25 and 45 DAS and was at par with foliar application of silicic acid $0.2 \%$. The increased plant height due to PPFM was confirmed by the research of Suresh Reddy (2002). Increase in plant height in the present study might have been due to the combined effect of auxin and cytokinin production by PPFM, which allowed a balanced growth of shoot and root system.

\section{Leaf area index at harvest}

The leaf area index (LAI) at the crop growth stages varied significantly with irrigation regime and management practices (Table 1).
Among the irrigation regimes IW/CPE 1.0 recorded higher leaf area index of 3.77 at harvest stage which was comparable with IW/CPE 0.8 (3.73). The increased LAI obtained at the higher regime was due to favorable soil moisture supply, which led to an increase in LAI.

The effect of moisture stress on cell expansion and cell division has been known for a long time and a direct consequence of such effect has adversely affected the LAI (Farooq et al., 2010).

Foliar application of PPFM $1 \%$ registered higher leaf area index of 3.62 which was at par with foliar application of silicic acid $0.2 \%$. Pink pigmented facultative methylobacteria produced plant growth regulators, resulting in diverse physiological effect over the crop stimulating the division, extension and differentiation of plant cells eventually enhancing plant growth parameters like plant height, total leaf area, number of branches (Muromtsev et al., 1987).

\section{Total Dry Matter Production}

Irrigation scheduling and drought management practices significantly influenced the crop dry matter production. IW/CPE 1.0 and 0.8 recorded significantly higher and comparable dry matter production of $16159 \mathrm{~kg} \mathrm{ha}^{-1}$ and $15873 \mathrm{~kg} \mathrm{ha}^{-1}$ respectively. IW/CPE 0.4 recorded distinctly lower dry matter production (12647 $\left.\mathrm{kg} \mathrm{ha}^{-1}\right)$.

Reduction in dry matter accumulation under lower irrigation regime is because of reduced water availability which leads to water deficit condition for most of the crop growing period. Biomass accumulation is sensitive to water stress and the degree of reduction of biomass accumulation depended on the severity of water stress. The results are in line with the Guo et al., (2010). 
Table.1 Influence of moisture stress management practices on growth and yield of summer irrigated maize (Pooled data of two years)

\begin{tabular}{|c|c|c|c|c|}
\hline Treatment & $\begin{array}{l}\text { Plant height } \\
\text { (cm) }\end{array}$ & LAI & $\underset{\left(\mathrm{kg} \mathrm{ha}^{-1}\right)}{\text { DMP }}$ & $\begin{array}{c}\text { Yield } \\
\left(\mathrm{kg} \mathrm{ha}^{-1}\right)\end{array}$ \\
\hline \multicolumn{5}{|c|}{ Irrigation regimes } \\
\hline $\mathbf{I}_{1.0}$ & 217.6 & 3.77 & 16159 & 6715 \\
\hline $\mathbf{I}_{0.8}$ & 215.6 & 3.73 & 15873 & 6684 \\
\hline $\mathbf{I}_{0.6}$ & 194.3 & 3.34 & 14067 & 5940 \\
\hline $\mathbf{I}_{0.4}$ & 178.8 & 3.07 & 12647 & 4728 \\
\hline SEm \pm & 1.9 & 0.04 & 135 & 54 \\
\hline $\mathrm{CD}(\mathrm{p}=0.05)$ & 6.7 & 0.11 & 468 & 186 \\
\hline \multicolumn{5}{|c|}{ Moisture stress management practices } \\
\hline FPPM $_{\text {PPM }}$ & 209.7 & 3.62 & 15505 & 6381 \\
\hline $\mathbf{F}_{\mathrm{Br}}$ & 198.6 & 3.42 & 14322 & 5869 \\
\hline $\mathbf{F}_{\mathrm{SI}}$ & 205.2 & 3.54 & 14898 & 6138 \\
\hline $\mathbf{F}_{\mathrm{C}}$ & 192.8 & 3.32 & 14020 & 5679 \\
\hline SEm \pm & 1.7 & 0.03 & 120 & 54 \\
\hline $\mathrm{CD}(\mathrm{p}=\mathbf{0 . 0 5})$ & 5.0 & 0.09 & 348 & 158 \\
\hline \multicolumn{5}{|l|}{ Interaction } \\
\hline $\mathbf{I}_{1.0} \mathbf{F}_{\text {PPFM }}$ & 221.4 & 3.83 & 16604 & 6819 \\
\hline $\mathbf{I}_{1.0} \mathbf{F}_{\mathrm{Br}}$ & 216.4 & 3.74 & 16125 & 6708 \\
\hline $\mathbf{I}_{1.0} \mathbf{F}_{\mathrm{SI}}$ & 218.1 & 3.77 & 16311 & 6743 \\
\hline $\mathbf{I}_{1.0} \mathbf{F}_{\mathbf{C}}$ & 214.5 & 3.71 & 15594 & 6589 \\
\hline $\mathbf{I}_{0.8} F_{\text {PPFM }}$ & 220.5 & 3.82 & 16475 & 6784 \\
\hline $\mathbf{I}_{0.8} \mathbf{F}_{\mathrm{Br}}$ & 217.2 & 3.76 & 15568 & 6670 \\
\hline $\mathbf{I}_{0.8} \mathbf{F}_{\mathrm{SI}}$ & 218.0 & 3.77 & 15840 & 6724 \\
\hline $\mathbf{I}_{0.8} F_{C}$ & 206.8 & 3.57 & 15608 & 6557 \\
\hline $\mathbf{I}_{0.6} F_{\text {PPFM }}$ & 202.9 & 3.50 & 14899 & 6491 \\
\hline $\mathbf{I}_{0.6} F_{\mathrm{Br}}$ & 189.1 & 3.25 & 13597 & 5675 \\
\hline $\mathbf{I}_{0.6} \mathbf{F}_{\mathrm{SI}}$ & 197.9 & 3.41 & 14369 & 6153 \\
\hline $\mathbf{I}_{0.6} F_{C}$ & 187.2 & 3.22 & 13402 & 5443 \\
\hline $\mathbf{I}_{0.4} F_{\text {PPFM }}$ & 194.0 & 3.34 & 14043 & 5432 \\
\hline $\mathbf{I}_{0.4} \mathbf{F}_{\mathrm{Br}}$ & 171.6 & 2.94 & 11998 & 4424 \\
\hline $\mathbf{I}_{0.4} \mathbf{F}_{\mathrm{SI}}$ & 187.0 & 3.21 & 13070 & 4932 \\
\hline $\mathbf{I}_{0.4} \mathbf{F}_{\mathrm{C}}$ & 162.7 & 2.77 & 11475 & 4127 \\
\hline SEm \pm & 3.5 & 0.06 & 248 & 108 \\
\hline $\mathrm{CD}(\mathrm{p}=\mathbf{0 . 0 5})$ & 10.9 & 0.19 & 762 & 330 \\
\hline
\end{tabular}

Note: $\mathrm{I}_{1.0}, \mathrm{I}_{0.8}, \mathrm{I}_{0.6}$ and $\mathrm{I}_{0.4}$ are Irrrigation regimes of IW/CPE ratio 1.0, 0.8, 0.6 and 0.4 respectively $\mathrm{F}$ - Foliar application at 25 and 40 DAS; PPFM - Pink pigmented facultative methylobacteria $1 \%$;

Sl-Silicic acid $0.2 \% ; \mathrm{Br}-$ Brassinolide $0.1 \mathrm{ppm}$ and $\mathrm{C}$ - Control 
Table.2 Influence of moisture stress management practices on economics of summer irrigated maize (Pooled data of two years)

\begin{tabular}{|c|c|c|c|c|}
\hline Treatment & $\begin{array}{c}\text { Cost of cultivation } \\
\left(\text { Rs. } \text { ha }^{-1}\right)\end{array}$ & $\begin{array}{l}\text { Gross return } \\
\left(\text { Rs. ha }^{-1}\right)\end{array}$ & $\begin{array}{l}\text { Net Return } \\
(\text { Rs. ha }\end{array}$ & Benefit: cost ratio \\
\hline \multicolumn{5}{|c|}{ Irrigation regimes } \\
\hline $\mathbf{I}_{1.0}$ & 33448 & 88656 & 55208 & 2.65 \\
\hline $\mathbf{I}_{0.8}$ & 32611 & 88146 & 55535 & 2.71 \\
\hline $\mathbf{I}_{0.6}$ & 31436 & 78318 & 46882 & 2.49 \\
\hline $\mathbf{I}_{0.4}$ & 30848 & 63065 & 32216 & 2.04 \\
\hline \multicolumn{5}{|c|}{ Moisture stress management practices } \\
\hline $\mathbf{F}_{\text {PPFM }}$ & 32875 & 84330 & 51455 & 2.56 \\
\hline $\mathbf{F}_{\mathrm{Br}}$ & 31969 & 77593 & 45624 & 2.42 \\
\hline $\mathbf{F}_{\mathrm{SI}}$ & 33175 & 81103 & 47929 & 2.44 \\
\hline $\mathbf{F}_{\mathbf{C}}$ & 30325 & 75158 & 44833 & 2.47 \\
\hline \multicolumn{5}{|l|}{ Interaction } \\
\hline $\mathbf{I}_{1.0} \mathbf{F}_{\text {PPFM }}$ & 34237 & 90130 & 55892 & 2.63 \\
\hline $\mathbf{I}_{1.0} \mathbf{F}_{\mathrm{Br}}$ & 33331 & 88557 & 55225 & 2.66 \\
\hline $\mathbf{I}_{1.0} F_{S l}$ & 34537 & 89068 & 54531 & 2.58 \\
\hline$I_{1.0} F_{C}$ & 31687 & 86870 & 55182 & 2.74 \\
\hline $\mathbf{I}_{0.8} \mathrm{~F}_{\mathrm{PPFM}}$ & 33400 & 89647 & 56248 & 2.68 \\
\hline $\mathbf{I}_{0.8} \mathbf{F}_{\mathrm{Br}}$ & 32494 & 87829 & 55335 & 2.70 \\
\hline $\mathbf{I}_{0.8} \mathbf{F}_{\mathrm{Sl}}$ & 33700 & 88613 & 54913 & 2.63 \\
\hline $\mathbf{I}_{0.8} \mathbf{F}_{\mathbf{C}}$ & 30850 & 86494 & 55644 & 2.80 \\
\hline$I_{0.6} F_{P P F M}$ & 32225 & 85339 & 53114 & 2.65 \\
\hline $\mathbf{I}_{0.6} \mathbf{F}_{\mathrm{Br}}$ & 31319 & 74902 & 43583 & 2.39 \\
\hline $\mathbf{I}_{0.6} \mathbf{F}_{\mathrm{Sl}}$ & 32525 & 81017 & 48492 & 2.49 \\
\hline $\mathbf{I}_{0.6} \mathbf{F}_{\mathrm{C}}$ & 29675 & 72012 & 42337 & 2.43 \\
\hline $\mathbf{I}_{0.4} \mathbf{F}_{\text {PPFM }}$ & 31637 & 72202 & 40565 & 2.28 \\
\hline $\mathbf{I}_{0.4} \mathbf{F}_{\mathrm{Br}}$ & 30731 & 59083 & 28352 & 1.92 \\
\hline $\mathbf{I}_{0.4} \mathbf{F}_{\mathrm{SI}}$ & 31937 & 65715 & 33778 & 2.06 \\
\hline $\mathbf{I}_{0.4} \mathbf{F}_{\mathbf{C}}$ & 29087 & 55258 & 26170 & 1.90 \\
\hline
\end{tabular}

Statistically not analysed

Note: $\mathrm{I}_{1.0}, \mathrm{I}_{0.8}, \mathrm{I}_{0.6}$ and $\mathrm{I}_{0.4}$ are Irrrigation regimes of IW/CPE ratio 1.0, 0.8, 0.6 and 0.4 respectively

$\mathrm{F}$ - Foliar application at 25 and 40 DAS; PPFM - Pink pigmented facultative methylobacteria $1 \%$;

Sl-Silicic acid $0.2 \%$; $\mathrm{Br}$ - Brassinolide 0.1ppm and $\mathrm{C}$ - Control.

Foliar spray of PPFM produced substantially higher DMP of $15505 \mathrm{~kg} \mathrm{ha}^{-1}$ around 12.4 per cent over control. In water deficit condition under IW/CPE ratio of 0.4 increased the dry matter production by 20.4 per cent over the control. The increase might have been due to the production of growth hormones viz., IAA, cytokinin and gibberellic acid influencing dry matter production. Moreover cytokinin antioxidant properties protected the leaves from stress induced oxidation. This was justified by finding of Zhang and Ervin (2008). 


\section{Yield}

Irrigation scheduling and drought management significantly influenced the yield of the crop (Table 1). IW/CPE 1.0 and 0.8 recorded conspicuously higher and comparable grain yield of 6715 and $6684 \mathrm{~kg}$ $\mathrm{ha}^{-1}$. The increase in yield could be attributed to greater and consistent available soil moisture due to increased level of irrigation that resulted in better crop growth and yield components. Similar findings were reported by Zhao et al., (2010).

The lower yield in irrigation at IW/CPE of 0.4 might be attributed to the decrease in synthesis of metabolites and reduction in absorption and translocation of nutrients from soil to plant under deficit moisture supply. Among the foliar application treatments foliar application of PPFM recorded distinctly higher grain yield of $6381 \mathrm{~kg} \mathrm{ha}^{-1}$ followed by foliar application of silicic acid $6138 \mathrm{~kg} \mathrm{ha}^{-1}$. The yield increase with the foliar application of PPFM was due to the increased plant growth parameters like plant height, leaf area, and total biomass, corroborating the results of Madhaiyan et al., (2005).

\section{Economics}

Higher net return (INR 55,535) and B: C ratio (2.71) was attained under IW/CPE ratio 0.8 and was followed by IW/CPE ratio of 1.0. Among the foliar application treatments foliar application of PPFM 1\% recoded higher net return and $\mathrm{BC}$ ratio (INR 51,455; 2.56 respectively) followed by silicic acid $0.2 \%$. This might be due to higher grain yield even under water stressed (IW/CPE 0.6) condition (Sumathi and Rao 2008) (Table 2).

In interaction effect irrigating at IW/CPE 0.8 with foliar application of PPFM 1\% recorded higher net return (Rs. 56,248) however higher $\mathrm{BC}$ ratio were obtained in IW/CPE 0.8 with no moisture stress management practice (2.80). Under mild or no moisture stress condition the foliar application treatments will not be cost effective hence control recorded higher benefit cost ratio.

From the present study it can be concluded that irrigating at IW/CPE 0.8 (12 days interval) is ideal for obtaining higher yield, net return and cost benefit under normal condition. While under water scarcity condition irrigating at IW/CPE ratio of 0.6 (16 days interval) with foliar application of PPFM $1 \%$ on 25 and 45 DAS was found to be suitable for sustaining the yield, net return and cost benefit.

\section{References}

Alagar Pandyan, V. and Iruthayaraj, M. R. (1991). Effect of irrigation, nitrogen and plant population on growth and yield of MCU 9 cotton. Agri. Sci. Digest, 11(4): 219-222.

Chen, W., Yao, X., Cai, K. and Chen, J. (2011). Silicon alleviates drought stress of rice plants by improving plant water status, photosynthesis and mineral nutrient absorption. Biological trace element research, 142(1), 67-76.

Daryanto S., Wang L. and Jacinthe P. A. (2016). Global synthesis of drought effects on maize and wheat production. PLOS ONE $11: \mathrm{e} 0156362$ 10.1371/journal.pone. 0156362

Farooq, M., Wahid, A., Lee, D. J., Cheema, S. A. and Aziz, T. (2010). Drought stress: comparative time course action of the foliar applied glycinebetaine, salicylic acid, nitrous oxide, brassinosteroids and spermine in improving drought resistance of rice. Journal of Agronomy and Crop Science, 196(5), 336-345.

Gong, B., Chen, Q. and Wang, D. (2012). Molecular dynamics study on sizedependent elastic properties of silicon nanoplates. Materials Letters, 67(1), 165168 .

GOR, (2007). Economic development and poverty reduction strategy. Ministry of Finance and 
Economic Planning, Kigali, Rwanda.

Guo, J., Yang, Y., Wang, G., Yang, L. and Sun, X. (2010). Ecophysiological responses of Abies fabri seedlings to drought stress and nitrogen supply. Physiologia Plantarum, 139(4), 335-347.

Irvine, I. C., Brigham, C. A., Suding, K. N. and Martiny, J. B. (2012). The abundance of pink-pigmented facultative methylotrophs in the root zone of plant species in invaded coastal sage scrub habitat. PloS one, 7(2), e31026.

Ma, J. F. (2004). Role of silicon in enhancing the resistance of plants to biotic and abiotic stresses. Soil science and plant nutrition, 50(1), 11-18.

Madhaiyan, M., Sundaram, S. P. and Kannaiyan, S. (2005). Influence of Pink pigmented facultative methylotrophic bacteria on the seedling vigour of maize (Zea mays L.). $J$. Microbiol. World., 4: 117-121.

Muromtsev, G. V., Chkanikov, D. I., Kulaeva, O. N. and Hamburg. (1987). The hormonal regulation of physiological process in flowering plants. Agropromizdat, pp. 80133.

Rao, S. S. R., Vardhini, B. V., Sujatha, E., \& Anuradha, S. (2002). Brassinosteroids-a new class of phytohormones. Current Science, $1239^{-1} 245$.

Ryu, H., Kim, K., Cho, H., Park, J., Choe, S. and Hwang, I. (2007). Nucleocytoplasmic shuttling of BZR1 mediated by phosphorylation is essential in Arabidopsis brassinosteroid signaling. The Plant Cell, 19(9), 2749-2762.

Sasse, J. M. (1997). Recent progress in brassinosteroid research. Physiologia Plantarum, 100(3), 696-701.

Shen, X., Zhou, Y., Duan, L., Li, Z., Eneji, A. E. and Li, J. (2010). Silicon effects on photosynthesis and antioxidant parameters of soybean seedlings under drought and ultraviolet-B radiation. Journal of plant physiology, 167(15), 1248-1252.

Singh, Y., Rao, S. S. and Regar, P. L. (2010). Deficit irrigation and nitrogen effects on seed cotton yield, water productivity and yield response factor in shallow soils of semi-arid environment. Agricultural Water Management, 97(7), 965-970.

Sumathi, V and DS Koteswara Rao. 2008. "Interaction effects of irrigation and nitrogen management on production of sunflower (Helianthus annus L.)." Current Biotica 2 (1):9-17.

Suresh Reddy, B. V. (2002). Studies on PPFM as a new bioinoculant for groundnut. M. Sc. (Agri.) Thesis, TNAU, Coimbatore.

Tripathi, D. K., Singh, V. P., Gangwar, S., Prasad, S. M., Maurya, J. N. and Chauhan, D. K. (2014). Role of silicon in enrichment of plant nutrients and protection from biotic and abiotic stresses. In Improvement of crops in the era of climatic changes (pp. 39-56). Springer, New York, NY.

Wingler, A., Lea, P. J., Quick, W. P. and Leegood, R. C. (2000). Photorespiration: metabolic pathways and their role in stress protection. Philosophical Transactions of the Royal Society of London. Series B: Biological Sciences, 355(1402), 1517-1529.

Zhang, X. and Ervin, E. H. (2008). Impact of seaweed extract-based cytokinins and zeatin riboside on creeping bentgrass heat tolerance. Crop Science, 48(1), 364-370.

Zhao, C., Yan, Y., Yimamu, Y., Juyan, Zhao, Z. and Laosheng, W.U. (2010). Effects of soil moisture on cotton root length density and yield under drip irrigation with plastic mulch in Aksu oasis farmland. Journal of arid land, 2(4): 243-249

\section{How to cite this article:}

Rajasekar, M. and Prabhakaran, N. K. 2020. Influence of Moisture Stress Management Practices on the Performance of Summer Irrigated Maize (Zea mays L.). Int.J.Curr.Microbiol.App.Sci. 9(04): 1717-1723. doi: https://doi.org/10.20546/ijcmas.2020.904.202 